$10 \mid 2021$

Intelligence artificielle, pratiques sociales et politiques publiques

\title{
Online Migration of Musical Instrument Teachers : Technology, AI, and New Professional Perspectives
}

Migration en Ligne des Professeurs d'Instruments de Musique: Technologie, IA et Nouvelles Perspectives Professionnelles

Ingrid Barbosa

(2) OpenEdition

Journals

Electronic version

URL: https://journals.openedition.org/ctd/5015

DOI: $10.4000 /$ ctd. 5015

ISSN: 2491-1437

\section{Publisher}

Chaire Unesco Pratiques émergentes en technologies et communication pour le développement

Printed version

ISBN: 2491-1437

Electronic reference

Ingrid Barbosa, "Online Migration of Musical Instrument Teachers : Technology, Al, and New Professional Perspectives", Communication, technologies et développement [Online], 10 | 2021, Online since 20 May 2021, connection on 28 May 2021. URL: http://journals.openedition.org/ctd/5015 ; DOI: https://doi.org/10.4000/ctd.5015

This text was automatically generated on 28 May 2021

Communication, technologies et développement 


\title{
Online Migration of Musical
} Instrument Teachers : Technology, AI, and New Professional Perspectives

\author{
Migration en Ligne des Professeurs d'Instruments de Musique: Technologie, IA \\ et Nouvelles Perspectives Professionnelles
}

Ingrid Barbosa

\section{EDITOR'S NOTE}

Migração Online de Professores de Instrumentos Musicais : Tecnologia, IA e Novas perspectivas profissionais

O presente trabalho traz à frente a discussão sobre o processo de migração online de professores de instrumentos musicais no Brasil durante a pandemia do covid-19 ocorrida no ano de 2020, discutindo os principais desafios enfrentados de acordo com resultados de uma pesquisa realizada anteriormente. 0 objetivo foi promover o diálogo entre as adaptações para o online e o uso de tecnologia para aulas de música através das oportunidades encontradas no uso de inteligência artificial aplicada à pesquisa em música e educação musical. As conclusões nos levam a pensar que há um grande espaço a ser explorado combinando IA ao ensino de música e que, embora deva ser usado com cautela, respeitando as necessidades e complexidade da música, a inovação nesse sentido pode prover ferramentas e meios de apoiar e ampliar oportunidades para a profissão do músico em meio a diversos contextos.

Ensino de música ; ensino online ; cibercultura ; inteligência artificial ; inovação profissional

1 Brazilian internet studies scholar André Lemos (2010) once stated that "we should diagnose the present, tension it with the past to think on the future". The challenges 
posed by the covid-19 pandemic faced during year 2020 revealed that, while that is great advice, it is sometimes difficult to take time for reflection and decision making when it comes to emergency situations. The social restriction measures taken by most countries caused online migration in all kinds of business to become compulsory, at least for the moment. Just like all other areas, education was deeply affected by the changes and had to immediately adapt to fit the "new normal".

Music education followed the same path, leaving many questions unanswered specially to musical instrument teachers, who were mostly unaware of online solutions and strategies for their work to be accomplished. Their challenges, however, go beyond merely migrating to online platforms. For the most of them, comprehending the digital universe is far from their domain, leading to situations such as: "a) lack of understanding about the virtual logic and its implications ; b) lack of knowledge about professional positioning and entrepreneurship in digital channels ; c) need of qualified training for online teaching" (Barbosa, $2020: 2$ ).

3 An investigative study was carried through a quantitative questionnaire regarding the adaptation experience of musical instrument teachers to the online space and its immediate results on their students' learning process considering teaching-learning strategies, teaching instrument abilities and techniques, and maintenance of values and interpersonal exchanges. The goals of the survey were to : identify the main challenges faced by these teachers during the covid-19 pandemic in Brazil ; detect positive and negative factors of this teaching forms regarding musical instruments instruction; and to find insights for future research approaches in this theme (Barbosa, 2020).

4 In this sense, the aim of the present work is to add a relevant element that has emerged in various fields : artificial intelligence (AI). We will discuss how AI could contribute to the work of musical instrument teachers, alongside with other technologies that have already begun to be explored by this group of professionals, particularly due to the pandemic. To better organize this work, we will carry it in three parts : first, a brief review $^{1}$ on the results of the survey administered to the musical instrument teachers, which will serve as a guideline to the discussion along the paper; second, to outline how has AI been used in music areas in the present and what would be its possible applications to instrument lessons ; finally, to draw considerations on AI and human interaction concerns for healthy music learning while keeping an opened mind to the emerging opportunities and needs of the virtual era.

\section{What the questionnaires told us about online musical instrument lessons}

5 As previously mentioned, the early stage of this research was built by a theoretical discussion on the impact of cyberculture on music teachers followed by a quantitative research through online questionnaires addressed to private and school ${ }^{2}$ musical instrument teachers. In short, cyberculture is the era in which all relations become mediated by technology (Lemos, Lévy, 2010 ; Trivinho, 2007 ; Sodré, 1996). Lemos and Lévy (2010) state it is the era founded in constant connectivity and interaction, social reconfiguration and collective spaces, and the integration of all individuals as possible speakers/ actors. Brazilian scholar Eugênio Trivinho (2007), however, points that velocity is the main violence in cyberculture, as it obligates us to be in constant 
optimization - a process he calls dromoaptitude, in which case if you are not apt you will be forgotten or excluded.

This is part of the social order transformation caused by technological impregnation that defines technoculture (Sodré, 2001) and shifted the ontology of arts and culture. In this sense, teachers can no longer rely only on their traditional formation. They must prepare for the online context with new skills, such as new methodologies, audio and image editing, digital marketing, entrepreneurship, influencing. Such things are part of keeping oneself updated, visible and interesting to the media and consequently possible clients ; such process was strongly accentuated during the covid-19 lockdown.

7 To bring some more context on the music profession, it is worth mentioning that musical instrument teachers and orchestra players in Brazil face working situations marked by "flexibility, instability, informality and precariousness" and often need to search for multiple sources of income to meet their financial needs, as it was discussed in a study by Bartz (2020) about the professional identity of Brazilian musicians, especially instrument players. Hence, even before the pandemic there has always been a strive to broaden the reach of musical instrument teaching - musicians in Brazil commonly work as teachers in more than one school or project, besides playing in an orchestra or other music groups, gigs, and doing private teaching.

Moving forward to the online migration matter, Nestor García Canclini offers us another perspective regarding the results of the digital era transformation when stating that the field of legitimate culture was broadened (Canclini, $2016: 15)$ because our relation towards institutions and objects has changed thus changing our culture and consumption habits. He also discusses that research often seeks for answers to questions that are no longer made. Perhaps, how music teachers view their work also needs new questions to provide answers and ideas that better suit our new living (Barbosa, 20193).

With this in mind, whereas anticipating some resistance in the opinions about online lessons, a questionnaire was made in Google Forms and shared via social media (WhatsApp group, Facebook and Instagram). The questions allowed multiple answers and were answered by 34 Brazilian musical instrument teachers currently working in Brazil aged 18 to above 50 years old (Barbosa, 2020). The research was accomplished after about four months of isolation due to covid-19 restriction measures. An interesting fact about the participant teachers is that 15 taught multiple instruments, which takes us back to the work of Bartz (2020) revealing multiple working activities for musicians. The responses brought four main points to reflection ${ }^{4}$ (Barbosa, 2020) :

101 . The online teaching migration process was unsatisfying because it was sudden. Many teachers believe that had they been prepared, they would have a positive view about it [16]; no teachers received training for the online model of music lessons; some teachers affirmed to have been at ease with the use of technology [13]. Most participants seemed opened to get more prepared and many [19] believed online classes should be considered even after the pandemic.

11 2. Concerning the positive and negative factors in the music teaching-learning process : a) mostly positive responses for music theory, basic instrument technique, expansion of music contextual knowledge ; b) mostly negative responses for advanced instrument technique, music interpretation, sound/ tone development, and group practice. The large range of answers may indicate that some limitations and difficulties during the 
lessons are not only related the technological gadgets, but also to the teacher's different abilities and understandings of their instrument, or to the creativity and development of strategies to use technology as a mediator for the lessons.

3. About physical distance, most teachers [20] said it made more difficult to work certain contents ; few teachers [5] affirmed it is impossible for the student to reach full comprehension in online lessons. An additional remark stated that the lack of presence slowed down the achievement of some results that would be faster if there could be demonstration through touch. Many teachers [17] believe the difficulties can be dealt with once there is adequate preparation for online lessons. The impossibility of group practice and performance was viewed negatively by other teachers [12], while only some noted actual loss in the student teacher relationship [7]. At last, few teachers [3] said they did not feel any loss from the online distance and such belief is a result of traditionalism and technophobia.

13 4. When asked about their post-pandemic teaching plans, the responses were fairly divided between returning to only presential classes [10] and returning to presential classes but maintaining private online students [9], while a higher number of teachers [15] affirmed they hoped music schools would maintain a hybrid teaching system. No teachers showed intention of keeping online lessons only, nor agreed to a hypothetical situation in which individual lessons would be online and group practice would be presential.

14 Some extra teachers who did not migrate to online were questioned. Their reasons for not migrating were: unacceptance of students to the format, lack of interest or enjoyment in online teaching, preference for exploring other work alternatives during the pandemic.

\section{Possibilities for artificial intelligence use in music teaching}

15 At this point we would like to observe more closely the negative aspects of the online musical instrument lessons and their pointed frailties. The strongest [30] negative factor was poor conditions for working sound and tone - which is the main element to be perfected by music students. Although Zoom allows you to enable original audio and skip the compression, this seems not to be sufficient for more sensitive aspects of sound/tone abilities. The second strongest negative factor [14] was the absence of group music practice (Barbosa, 2020). Bringing orchestras, chamber music or group classes online is difficult due to connectivity problems, sound quality loss and limited interactions.

16 Teachers' response also pointed great disadvantage in teaching advanced technique and more time spent to explain certain technical and interpretative contents. Also, the positive aspects did not have expressive numbers : music theory [12]; music history comprehension [11]; and basic technique [11]. This seems to indicate that there was less excitement towards the good results of online teaching compared to the complains of the negative results (Barbosa, 2020).

17 Could artificial intelligence be applied to reverse some of those problems or optimize the positive points? We will now focus on some examples of present uses of AI in music research, practice, and teaching. The works of Teixeira et al. $(2014,2015)$ analyzed the 
body movements of clarinet players using NDI Optotrak Certus and Optotrak $3020^{5}$ devices, which measure and map all kinetics and motions when wired to certain points of one's body. Their work analyzed the relation between repeated body movements of players while performing a given musical excerpt regarding the musical content in technical and interpretative matters. The device operates in VR and AI basis, registering all movements produced by the wired body and revealing measures that were put into an algorithm to later become a graphic.

Although the study did not relate to a teaching situation, performance is the ultimate goal of music learning. The referred study analyzed how repeated gestures and motions can show satisfaction and relaxation, or concern and anxiety while playing an instrument - something challenging to accurately observe and work in remote music lessons. Although this apparel is not be viable for teachers in their daily basis, it could certainly encourage future developments of AI monitoring and translating kinetics to a teacher while watching a student's video recorded or live performance, for example.

Simon Holland (2000) presents a historical review of AI in music education and introduces useful AI-based software that could be applied to music teaching, though his paper focuses mostly on composition learning tools. To Holland, one of the main challenges in using AI in music education is that while AI is mostly problem solving, composition and music interpretation are problem seeking because music is an openended knowledge and teaching it means to be in a continuum of possibilities between getting problems and finding creative resolutions.

20 The author depicted the early phase of AI-ED software for music, from the 1970s to mid 1980s, as highly influenced by Intelligent Tutoring Systems (ITS). Holland (2000) brings Vivace, MacVoice and Lasso as examples - all of them used for composition, voice leading and harmonisation learning - with some criticism towards their textbook-rules emphasis and excessive negative remarks that limited students to learn what not to do and did not promote positive and sensible notions for their knowledge growth; in music, aesthetics can matter more than a set of rules.

21 On the other hand, the Logo philosophy through the creation of open-ended microworlds is particularly favorable to music learning and are associated to the constructivist approach. The Barmberger's Music Logo System and the LOCO series exemplified by Holland (2000) are AI built and used for managing, creating, and structuring music melodies and harmonies in a way that leads learners to build their own knowledge. However, the author remarks this type of software as an educational tool requires a human mediator and interaction with peers to be more effective. The merging of both systems, ITS and Logo microworlds, have led to more interactive interfaces and provided interesting virtual spaces for working music harmony.

22 An amazing AI music development is the creation of Smart Musical Instruments (SMI). According to Turchet (2018:8945), they integrate "embedded computation, real-time feature extraction and sensor fusion, networked communication, and combination of gesture-to-sound parameters mapping with familiar playing techniques of conventional instruments" and are built in a way to support creativity and expressiveness of the musician, letting the individual feel in control despite the automatization features. They could make possible interconnected group performances and promote individual learning through smartification. Unfortunately, there are very few instrument models available, and the costs are high. 

teaching of musical instruments are: 1) to address sound quality and tone appropriately ; 2) to provide precise evaluation and instruction to the students ; 3) impossibility for group practice. On the other hand, online teaching seemed favorable for complementary musical learning (like music theory, music history, harmony), and for basic technique instructions.

In the Brazilian context, music educators Barros et al. (2019) developed an application with an artificial neural network capable of identifying notes of various instruments, recording a musical excerpt audio and matching it to an original exercise proposed by the teacher. The app then shows the student the performance flaws in the audio and sends the results to the teacher. Although limited to melodic corrections, it was created as a support tool for musical instrument teachers to follow students' daily practice and plan the following lessons.

During the covid-19 pandemic, a group of reserachers in the Federal University of Paraíba, Brazil, developed their own virtual learning space for music learning called AVAMUSIC, and an innovating AI software called "Manossolfa Digital". The software is an ear training resource using a popular music education method developed by Hungarian composer and music educator Zoltán Kodaly that combines hand gestures with musical notes and intervals (Sales, Beltrame, Batista, 2021). Both creations were aimed to support musical instrument learning in the university classes and its extension programs.

There should be a concern regarding the social implications of using technology in music, for music is a social phenomenon and it exists through social relations. In this regard, music practice, interest in music learning and music consumption habits cannot be dissociated from immediate social, economic and cultural contexts (Söderman; Burnard; Trullson, 2015; Barbosa, 2019, 2020). Assuming access to technology is itself a social factor and the use of AI is even more limited, adding these aspects to musical instrument lessons could cause a wider abyss between social classes regarding opportunities of cultural exposition and growth, unless there are public and private investments on popularization of technology and AI in developing countries.

A further critical perspective derives from discussing the relationship between AI and human beings concerning the question of alterity. For instance, Heidegger $(1977,1988)$ understands perceiving others as an exclusively human attribute. Meanwhile, technique is a way of unveiling, of bringing forth, and turns all beings into availability ; thus, humans also become available and their way-of-being happens through technology. In this sense, an AI is unable to reproduce humanness to its fullness including alterity, sensitiveness, flaws, and improvisations (Lacerda, Mattos, 2020). In music lessons, such human attributes are necessary for a more realistic and empathic relationship between teacher and student and music making.

\section{Future perspectives and considerations to musical instrument teachers}

As Holland (2000:17) well showed, "music is an open-ended area" in which "problemseeking is at least as important as problem solving". Though various AI-based music tools do not have a primary educational purpose, they have educational applications. 
The existing tools for areas like music theory, listening, composing, harmonisation and performance can be very useful but have limitations. However, the alternatives presented by Holland reveal diverse tools that can enhance the referred positive aspects of online teaching, as harmonisation and composition can lead to a more complete music learning to instrument players.

Although the study of Holland (2000) is not very recent, there was little evidence found on AI based programs that could suit musical instrument teaching fully in the present. The works of Barros et al. (2019) and Sales et al. (2021), which were aimed as tools for musical instrument lessons, provide support for the teacher but do not address the challenges pointed in this study. Teixeira et al. $(2014,2015)$ and Turcher $(2018)$ showed innovations that are not viable in an instrument teacher's daily routine but cast insights for future developments that could signalize inadequate tension and movements of the student or bring the students and teachers closer to a group performance in distance.

Through the listing of challenges faced in online music lessons, followed by the brief discussion of current and future applications of AI in music, we do not want to incur in the mistake pointed by Brazilian scholar Francisco Rüdiger (2007, 2008). He affirms modern technology is founded in a pretentious thought that machinery can solve problems and demands of all nature and that the ultimate solution is to have machinery overcome the human being. This idea echoes the quote of Ellul (1977:274) saying "technique has got to a point in its evolution where it transforms itself and progresses without any decisive human intervention, but by a kind of force that pushes it to growth and necessarily leads it to an incessant development".

Back to the previously quoted example of Canclini (2016), when analyzing book reading culture, he arguments that although not so many books have been read, information has been accessed by different means, and knowing how to read nowadays goes beyond understanding words, it also may include electronic paths and elements. What does this mean to music teachers? Perhaps that there are new ways to consume and learn musical instruments and that teaching strategies may comprise extra musical knowledge and preparation that are part of the new way of understanding the world.

As Canclini (2016, p. 16) states, "like cinema did not end the theater, nor television and video ended the cinema, nor did mobile phones end computers, there is no evidence to imagine digitalization will end the written culture". This also suits online instrument music lessons : as recorded performances are unlikely to end live performances in a concert hall, online teaching is also unlikely to end presential/ face-to-face lessons, and artificial intelligence should not end the need of a tutor/ teacher. Holland (2000) emphasized the importance of teachers being well trained in human-machine cooperation, motivation, and negotiation so that AI tools can be efficient for music teaching.

33 Technology should be viewed as an alternative that can be assessed to cope with limitations - like the covid-19 pandemic - and to promote different learning experiences that interact with the upcoming society. Thus, it is important that music professionals learn how to better deal and get prepared for online teaching. The risks of our society and the constant need of adaptation remind "we are all stuck in a great experience which is happening at the moment of our action" (Giddens, 1995 :93). Therefore, existential questions about our profession and role in society should not lead us into pessimism but stimulate us to develop critical reflections and dialogue 
towards possibilities that can expand our work, including musical instrument teaching. This paper also hopes to have encouraged other AI researchers to partner with musical instrument teachers, thus contributing to support and broaden opportunities of accessible and qualified culture and learning.

\section{BIBLIOGRAPHY}

Barbosa, I. (2019, July). o consumo da música erudita na pós-modernidade : distanciamentos da caracterização social atual. Poster Presented at the 4th Pan-American Conference of Music Education - ISME, Resistência, Argentina. https://bit.ly/3lEEG1c.

Barbosa, I. (2020, June) Ensino de instrumentos musicais no ambiente virtual : uma reflexão sobre a repentina migração para o online durante a pandemia do covid-19. Paper presented in the Virtual Simposium of ABCiber, Online. https://bit.ly/3p83Esc.

Bartz, G. F. (2020). Identidade profissional e música erudita : músicos de orquestra, trabalho flexível e os dilemas da profissão. Opus, 26(1), 1-23.

Barros, A. ; Luz, H. ; Baia, J. (2019). Inteligência artificial na educação musical. Revista de Informática Aplicada, 15(2).

Canclini, N. G. (2016). o mundo inteiro como um lugar estranho. São Paulo : Edusp.

Ellul, J. (1977). Le système technicien. Paris : Calmann-Levy.

Giddens, A. A vida em uma sociedade pós-tradicional. (1995). In : Giddens, A. ; Lash, S. ; Beck, U. (eds.). Modernização Reflexiva : Política, tradição e estética na ordem social moderna. São Paulo : Editora Unesp.

Heidegger, M., and William L. (1977). “The Question Concerning Technology.” Essay. In : The Question Concerning Technology and Other Essays, 3-35. New York : Harper and Row.

Heidegger, M. (1988). The Basic Problems of Phenomenology. Bloomington : Indiana University Press. Holland, S. (2000) Artificial Intelligence in Music Education : a critical review. In Miranda, E. (ed.) Readings in Music and Artificial Intelligence, Contemporary Music Studies, vol. 20. Harwood Academic Publishers, The Netherlands.

Lacerda, I. ; Mattos, T. R. (2020). Be Right Back : Humans, Artificial Intelligence and Dasein in Black Mirror. Communication, technologies et développement, 8. http:// journals.openedition.org/ctd/3353.

Lemos, A. ; Lévy, P. (2010). o futuro da internet : em direção a uma ciberdemocracia planetária. São Paulo : Editora Paulus.

Rüdiger, F. (2007). Introdução Às Teorias Da Cibercultura. Porto Alegre : Sulina.

Rüdiger, F. (2008). Cibercultura e Pós-Humanismo : Exercícios De Arqueologia e Criticismo. Porto Alegre : EDIPUCRS.

Sales, T. ; Beltrame, J. ; Batista, C. (2021). Avamusic : aplicação web voltada para o ensino de instrumento musical. Brazilian Journal of Development, 7(1), 4649-4663. 
Söderman, J. ; Burnard, P. ; Hofvander-Trulson, Y. (2015). Contextualizing Bourdieu in the field of music and music education. In : Burnard, P. ; Sôderman, J. ; Trulson, Y. (eds.). Bourdieu and the Sociology of Music. Farnham, United Kingdom : Ashgate Publishing.

Sodré, M. (2001). Reinventando a cultura : a comunicação e seus produtos. Petrópolis : Editora Vozes.

Teixeira, E. ; Wanderley, M. ; Yehia, H. ; Loureiro, M. (2014). Motion analysis of clarinet performers. Journal of New Music Research, May 2014.

Teixeira, E. ; Yehia, H. ; Loureiro, M. (2015). Relating movement recurrence and expressive timing patterns in music performances. The Journal of the Acoustic Society of America, 138(3).

Trivinho, E. (2007). A dromocracia cibercultural : lógica da vida humana na civilização mediática avançada. São Paulo : Editora Paulus.

Turchet, L. (2018). Smart musical instruments : vision, design principles and future directions. Institute of Electric and Electronics Engineers Journal, 7, 8944-8963.

\section{NOTES}

1. Complete results may be found in the work published specifically with the purpose of building and analyzing the results of the questionnaire (Barbosa, 2020).

2. The referred schools are independent music centers, unrelated to primary or secondary schools' compulsory classes.

3. The discussion of this work (Barbosa, 2019) concerns specifically the position, imagery and signs related to classical music in post-modernism and how this may impact its consumption and preferences due to keeping a more traditional view.

4. The number of responses to each comment will appear between brackets.

5. Information on the devices is available on the website of the company: https:// tracklab.com.au/products/brands/ndi/ndi-optotrak-certus/, however, the product has been discontinued and newer devices have taken place.

\section{ABSTRACTS}

The present work brings forth a discussion about the online migration process of musical instrument teachers in Brazil during the covid-19 pandemic in 2020, discussing majorly the challenges faced according to results of a survey carried in a previous study. The aim was to promote a possible dialogue between the online adaptations and the use of technology for music lessons with the opportunities found in the use of artificial intelligence applied to music studies and music education. The conclusions lead us to think that there is a large field to be explored in combining AI to music teaching and, although it must be used with caution, respecting the needs and complexity of music, innovation in this sense can provide tools and means to support and enlarge music profession opportunities amidst diverse contexts.

Cet article présente une discussion portant sur le processus de migration en ligne des professeurs d'instruments de musique au Brésil en 2020 pendant la pandémie de covid-19, en exposant les 
défis rencontrés selon les résultats d'une enquête menée dans une étude précédente. L'objectif était de promouvoir un dialogue possible entre les adaptations en ligne et l'utilisation de la technologie pour les cours de musique avec les opportunités offertes par l'utilisation de l'Intelligence Artificielle (IA) appliquée aux études musicales et à l'éducation musicale. Les conclusions nous amènent à penser que la combinaison de l'IA à l'enseignement de la musique constitue un large champ à explorer et, bien qu'elle doive être mise en œuvre avec prudence, en respectant les besoins et la complexité de la musique. En effet, l'innovation en la matière peut fournir des outils et des moyens importants pour soutenir et élargir les possibilités de la profession musicale dans différents contextes.

INDEX

Mots-clés: Enseignement de la musique ; enseignement en ligne ; cyberculture ; intelligence artificielle ; innovation professionnelle

Keywords: Music teaching ; online teaching ; cyberculture ; artificial intelligence ; professional innovation

\section{AUTHOR}

\section{INGRID BARBOSA}

Federal University of Bahia \& Adventist University of São Paulo, Brazil 